\title{
PENERAPAN AKUNTANSI PERTANGGUNGJAWABAN SEBAGAI ALAT BANTU MANAJEMEN DALAM MENILAI KINERJA BAGIAN PRODUKSI PT. CEMANI TOKA PERIODE 2013-2014
}

\author{
Akhsanul Haq \\ Dosen Tetap Fakultas Ekonomi Universitas Pakuan \\ Ardiana Christyaningrum \\ Mahasiswa Fakultas Ekonomi Universitas Pakuan
}

\begin{abstract}
ABSTRAK
Penelitian ini bertujuan untuk mengetahui penerapan akuntansi pertanggungjawaban sebagai alat bantu manajemen dalam menilai kinerja bagian produksi dengan studi kasus pada PT. Cemani Toka. Data penelitian ini diperoleh dari data hasil pengematan secara langsung pada perusahaan serta wawancara dengan pemimpin pada PT. Cemani Toka. Dengan metode analisis yang digunakan diskriptif kualitatif. Hasil penelitian menunjukan bahwa penerapan akuntansi pertanggungjawaban pada PT. Cemani Toka telah dilakukan dengan baik. Perusahaan telah penerapkan struktur oraganisasi, perencanaan anggaran, sistem akuntansi dan laporan pertanggungjawaban pada perusahaan. Sedangkan kinerja untuk bagian produksi pada PT. Cemani Toka menunjukkan kinerja yang cukup baik, bagian produksi sudah membuat laporan pertanggungjawaban dengan melaporkan antara biaya anggaran dengan biaya realisasinnya yang dapat digunakan manajer dalam mengendalikan biaya. Sehingga penerapan akuntansi pertanggungjawaban sebagai alat bantu manajemen dalam menilai kinerja bagian produksi pada PT. Cemani Toka mempunyai peran yang sangat penting.
\end{abstract}

Kata Kunci: Penerapan Akuntansi Pertanggungjawaban dan Kinerja Bagian Produksi

\section{Pendahuluan}

Pada era globalisasi persaingan yang terjadi di dunia ekonomi semakin ketat. Perusahaan dituntut untuk mampu mengidentifikasi, mengelola, dan memperbaiki proses bisnis yang penting. Agar perusahaan memperoleh keunggulan kompetitif dan dapat bertahan ditengah persaingan ketat dunia usaha. Perkembangan industri di Indonesia secara nasional belum memperlihatkan perkembangan. Bahkan perkembangan industri nasional, khususnya industri manufaktur, lebih sering terlihat merosot daripada grafik peningkatannya.
Salah satu cara yang bisa dilakuka perusahaan untuk menghadapi persaingan, yaitu dengan meningkatan kinerja perusahaan, setiap perusahaan berkeinginan untuk terus berkembang dan mendapatkan laba yang diinginkan. Dengan peningkatan kinerja, akan dapat mempengaruhi pencapaiaan tujuan perusahaan. Meningkatkan kinerja perusahaan tersebut perlu upaya manajemen dalam mengatur strategi agar mudah dalam melakukan pengendalian. Pada dasarnya pengendalian ini membantu seorang manajer atasan dalam mengatur tugas-tugas yang akan diberikan kepada manajer bawahannya 
agar mudah dalam melakukan pengontrolan. Upaya yang bisa dilakukan adalah dengan menerapkan akuntansi pertanggungjawaban.

Akuntansi pertanggungjawaban adalah sistem yang mengukur sebagai hasil yang dicapai oleh setiap pusat pertanggungjawaban menurut informasi yang dibutuhkan oleh para manajer untuk mengoperasikan pusat pertanggungjawaban mereka (Hansen and Mowen, 2013, 558).

Akuntansi pertanggungjawaban merupakan salah satu konsep dari akuntansi manajemen dan sistem akuntansi yang dikaitkan dan disesuaikan dengan pusat-pusat pertanggungjawaban yang ada dalam organisasi. Akuntansi pertanggungjawaban digunakan dalam mengukur kinerja setiap pusat pertanggungjawaban sesuai dengan informasi yang dibutuhkan manajer dalam mengoperasikan pusat pertanggungjawaban. Dalam membahas informasi akuntansi pertanggungjawaban sering kali berhubungan dengan wewenang yang dimiliki oleh tiap-tipa manajer, wewenang didelegasikan dari manajer atas ke manajer dibawahnya dan pendelegasian wewenang ini menuntut manajer bawah untuk mempertanggungjawabkan pelaksanaan wewenang kepada manajer atasannya.

Akuntansi pertanggungjawaban ini diharapkan dapat membantu manajer dalam pengalokasian biaya perusahaan agar lebih teranggarkan dan sistem akuntansi yang dibagi dalam pusat-pusat pertanggungjwaban akan lebih memudahkan dalam proses pengontrolan. Sehingga manajer dapat menilai kinerja dari setiap pusat-pusat pertanggungjawabannya agar permasalahan yang terjadi dapat segera teratasi. Dalam organisasi perusahaan, penentuan daerah pertanggungjawaban dan manajer yang bertanggungjawab dilaksanakan dengan menetapkan pusatpusat pertanggungjawaban dan tolak ukur kinerjanya. Menurut Hansen and Mowen $(2013,561)$, terdapat empat jenis pusat pertanggungjawaban, yaitu pusat biaya, pusat pendapatan, pusat laba, dan pusat investasi. Cara pusat-pusat pertanggungjawaban dibebankan mencerminkan situasi aktual dan jenis informasi yang tersedia bagi manajer.

Dari beberapa hasil penelitian terdahulu yang telah dikemukakan, menyatakan bahwa penerapan akuntansi pertanggungjawaban sangat berperan dalam pengendalian dan penilaian kinerja Sebagai alat pengendalian biaya dan penilaian kinerja, telah mencapai hasil yang efektif, dan dari beberapa hasil penelitian terdahulu menggunakan metode deskriptif kualitatif dengan cara membandingkan anggaran dan realisasinya yang ada dalam laporan pertanggungjawaban, kemudian dianalisis apa yang menyebabkan terjadinya varians antara anggaran yang telah ditetapkan dengan realisasinya. Maupun yang menggunakan metode analisis kuantitatif dengan regresi berganda dan uji hipotesis dengan cara membagikan kuesioner untuk mengetahui bagaimana penerapan akuntansi dan pengendalian. Sedangkan dalam penelitian yang akan penulis teliti menggunakan metode diskriptif kualitatif dengan melakukan studi langsung ke objek penelitian untuk mengetahui bagaimana penerapan akuntansi pertanggungjawaban sebagai alat bantu manjemen dalam menilai kinerja bagian produksi pada PT. Cemani Toka.

Ada pun tujuan dari penelitian ini adalah:

1. Untuk mengetahui penerapan akuntansi pertanggungjawaban pada PT Cemani Toka. 
2. Untuk mengetahui penilaian kinerja di bagian produksi pada PT Cemani Toka.

3. Untuk mengetahui penerapan akuntansi pertanggungjawaban sebagai alat bantu manajemen dalam menilai kinerja bagian produksi pada PT Cemani Toka.

\section{Tinjauan Pustaka}

2.1. Akuntansi Pertanggungjawaban Menurut Hansen dan Mowen (2013) akuntansi pertanggungjawaban adalah alat fundamental untuk pengendalian manajemen dan ditentukan melalui empat elemen penting, yaitu pemberian tanggung jawab, pembuatan ukuran kinerja (benchmarking), pengevaluasian kinerja, dan pemberian penghargaan.

Akuntansi pertanggungjawaban bertujuan memengaruhi perilaku dalam cara tertentu sehingga seseorang atau kegiatan perusahaan akan disesuaikan untuk mencapai tujuan bersama.

Sedangkan menurut Henry Simamora (2012), akuntansi pertanggungjawaban adalah sebuah sistem pelaporan informasi yang mengklasifikasikan data finansial menurut bidang-bidang pertanggungjawaban di dalam sebuah organisasi dan melaporkan berbagai aktivitas setiap bidang dengan hanya menyertakan kategori-kategori pendapatan dan biaya yang dapat dikendalikan oleh manajer yang bertanggung jawab.

Menurut Mulyadi (2001) syarat untuk dapat menerapkan akuntansi pertanggungjawaban, yaitu:

1. Struktur organisasi di mana harus menggambarkan aliran tanggung jawab, wewenang, dan posisi yang jelas untuk setiap unit kerja dari setiap tingkat manajemen. Selain itu, harus menggambarkan pembagian tugas dengan jelas pula. Dari hal tersebut, wewenang mengalir dari tingkat manajemen atas ke bawah, sedangkan tanggung jawab adalah sebaliknya.

2. Anggaran. Dalam akuntansi pertanggungjawaban setiap pusat pertanggungjawaban harus ikut serta dalam penyusunan anggaran karena merupakan gambaran rencana kerja para manajer yang akan dilaksanakan dan sebagai dasar dalam penilaian kinerjanya.

3. Penggolongan biaya. Pemisahan biaya ke dalam biaya terkendalikan dan tidak terkendalikan perlu dilakukan dalam akuntansi pertanggungjawaban karena tidak semua biaya yang terjadi di dalam satu bagian dapat dikendalikan oleh manajer, maka hanya biayabiaya terkendalikan yang harus dipertanggungjawabkan olehnya.

4. Sistem akuntansi biaya. Setiap tingkatan manajemen merupakan pusat biaya dan akan dibebani dengan biaya-biaya yang terjadi di dalamnya yang dipisahkan antara biaya terkendalikan dan tidak terkendalikan. Oleh karena biaya yang terjadi akan dikumpulkan untuk setiap tingkatan manajer maka biaya harus digolongkan dan diberi kode sesuai dengan tingkatan manajemen yang terdapat dalam struktur organisasi.

5. Sistem pelaporan biaya. Bagian akuntansi biaya setiap bulannya membuat laporan pertanggungjawaban disesuaikan dengan tingkat manajemen yang akan menerimanya.

\subsection{Kinerja Karyawan}

Kinerja menurut Rivai dan Basri (2004) adalah hasil kerja yang dapat dicapai oleh seseorang atau kelompok orang dalam suatu perusahaan sesuai dengan wewenang dan tanggung jawab 
masing-masing dalam upaya pencapaian tujuan perusahaan secara legal, tidak melanggar hukum, dan tidak bertentangan dengan moral dan etika. Sedangkan menurut Hadari Nawawi (2006) kinerja dikatakan tinggi apabila suatu target kerja dapat diselesaikan pada waktu yang tepat atau tidak melampaui batas waktu yang disediakan.

Menurut Robbins (2010) kinerja dapat dikatakan baik bila karyawan memenuhi hal-hal sebagai berikut:

1. Kualitas kerja: tingkat di mana hasil aktivitas yang dikehendaki mendekati sempurna dalam arti menyesuaikan beberapa cara ideal dari penampilan aktivitas maupun memenuhi tujuan yang diharapkan dari suatu aktivitas.

2. Kuantitas: jumlah yang dihasilkan dan dinyatakan dalam istilah seperti jumlah unit, dan siklus aktibitas yang diselesaikan.

3. Efektivitas: tingkat penggunaan sumber daya organisasi (tenaga, uang, teknologi, bahan baku) yang dimaksimalkan dengan maksud menaikkan hasil dari setiap unit dalam penggunaan sumber daya.

4. Kemandirian: tingkat di mana seorang karyawan dapat melakukan fungsi kerjanya tanpa meminta bantuan atau bimbingan dari orang lain atau pengawas.

5. Komitmen kerja: tingkat di mana karyawan mempunyai komitmen kerja dengan perusahaan dan tanggung jawab karyawan terhadap perusahaan.

\section{Metodologi Penelitian}

Jenis penelitian ini adalah studi kasus mengenai Penerapan Akuntansi Pertanggungjawaban untuk membantu Manajemen dalam Menilaian Kinerja Bagian Produksi pada PT. Cemani Toka perode tahun 2013 sampai dengan tahun 2014. Penelitian ini akan dibuktikan dengan menggunakan metode analisis deskriptif kualitatif.

Objek penelitian pada penelitian ini adalah variabel-variabel yang meliputi akuntansi pertanggungjawaban dalam menilai kinerja pada bagian produksi. Dalam penerapan akuntansi pertanggungjawaban, dapat digunakan untuk memberi penilaian teradap tugas yang telah diberikan pada setiap pusat pusat pertanggungjawaban yang telah dibentuk, penilaian ini menggunakan pendekatan melaluai pusat biaya untuk mengukur kinerja apakah sudah sesuai dengan tujuan perusahaan. Sedangkan untuk membahas objek atau variable yang diteliti, maka penulis memilih lokasi penelitian yang menjadi subjek penelitian yaitu pada PT. Cemani Toka.selama tahun 2013 sampai dengan tahun 2014.

Unit analisis yang digunakan adalah Organization, yaitu sumber data yang unit analisisnya merupakan respon suatu organisasi atau perusahaan. Dalam hal ini unit analisinya adalah PT. Cemani Toka selama tahun 2013 sampai dengan tahun 2014.

Lokasi pada penelitian ini adalah PT. Cemani Toka yang beralamat di Jalan Landbaw, KM 2,5, Citereup, Bogor. Perusahaan tersebut merupakan perusahaan yang bergerak di bidang industri tinta cetak.

Jenis data yang dikumpulkan adalah data kualitatif yaitu data yang diperoleh dari hasil observasi, FGD, wawancara, atau berupa uraian/ penjelasan mengenai variabel yang diteliti.

Sumber data yang digunakan adalah data primer yang diperoleh peneliti, langsung dari lokasi penelitian melalui wawancara dengan pimpinan departemen dan unit-unit dalam perusahaan yang berhubungan dengan objek penelitian sehingga dapat 
diperolah data dan informasi yang dibutuhkan.

\section{Hasil dan Pembahasan
4.1. Penerapan Akuntansi Pertanggungjawaban PT. Cemani Toka

Struktur organisasi PT. Cemani Toka secara jelas telah menggambarkan jenjang wewenang, tanggung jawab, tugas dan kewajiban setiap tingkatan manajemen dengan baik. Perusahaan juga telah merumuskan dengan jelas fungsi-fungsi pokok, tugas dan tanggung jawab pada setiap bagian unit kerja. Dengan adanya tugas dan wewenang yang jelas maka setiap tugas yang diberikan dapat dipertanggungjawabkan oleh setiap kepala bagian pada PT. Cemani Toka. Dapat dilihat dari uraian sebelumnya bahwa wewenang yang ada di PT. Cemani Toka didelegasikan dari manajer atasan ke manajer bawahannya, dari wewenang yang diberikan oleh manajer atasan tersebut menuntut manajer bawahan untuk mempertanggungjawabkan pelaksanaan wewenang kepada kepada pimpinan yang lebih tinggi. Sehingga dari struktur organisasi yang ada pada PT. Cemani Toka ini dapat kita ketahui bahwa wewenang mengalir dari manajer atas ke bawah, sedangkan tanggungjawab mengalir sebaliknya.Penerapan struktur organisasi yang terdapat di PT. Cemani Toka berbentuk vertikal menunjukkan bahwa terdapat pimpinan tertinggi atau presiden direktur yang bertanggungjawab atas pelaksanaan tugas yang telah ditentukan.

Proses penyusunan anggaran pada PT. Cemani Toka telah mengikut sertakan partisipasi manajer maupun staf-staf bagian. Penyusunan anggaran ini dilakukan per tahunan. Anggaran ini akan dibandingkan dengan realisasi yang hasilnya berupa laporan manajemen dan dilaporkan kepada manajer dan dewan direksi untuk dinilai sejauh mana kinerja perusahaan selama periode yang telah ditentukan.

PT. Cemani Toka dalam mengklasifikasikan biaya belum memisahkan antara biaya terkendali dengan biaya tidak terkendali. Pemisahan antara biaya-biaya yang terkendali dengan yang tidak terkendali sangat penting untuk menetapkan pusat pertanggungjawaban yang bertanggung jawab atas realisasi dan penyimpangan dari suatu anggaran. Manajemen dapat mengetahui di mana biaya terjadi dan siapa yang harus bertanggung jawab atas realisasi dan penyimpangan pada anggaran biaya.

PT. Cemani Toka telah melakukan pengkodean rekening untuk setiap perkiraan dengan sangant baik. Biayabiaya yang terjadi dicatat untuk setiap tingkat manajemen, kemudian digolongkan dan diberi kode sesuai dengan tingkatan manajemen yang terdapat dalam struktur organisasi. Klasifikasi dan kode rekening pada PT. Cemani toka telah dikaitkan dengan pusat pertanggungjawaban yang ada di dalam perusahaan. Dengan demikian kode rekening yang ada telah mencerminkan kewenangan pusat pertanggungjawaban dan mampu memberikan informasi mengenai pusat biaya dan manajer yang bertanggung jawab atas terjadinya biaya tersebut.

PT. Cemani Toka telah membuat laporan pertanggungjawaban berupa laporan realisasi anggaran tahunan. Pertanggungjawaban tiap unit usaha, dilakukan oleh masing-masing manajer yang bertanggungjawab yang nantinya akan melaporkan anggaran dan realisasi yang terjadi pada unit usaha tersebut ke kantor pusat. Periode laporan per tahun ini menunjukkan bahwa pemantauan kinerja dilakukan secara berkesinambungan terhadap unit kerja 
organisasi dalam mencapai sasaran yang telah ditetapkan.

\subsection{Penilaian Kinerja Bagian Produksi PT. Cemani Toka \\ PT. Cemani Toka memiliki tiga devisi produksi yang dipimpin oleh kepala produksi. Kepala produksi ini bertanggungjawab dalam pelaksanan produksi. Untuk mengetahui bagaimana kinerja dalam proses produksi ini kepala}

bagain bertanggungjaab penuh dalam keberhasilan devisi yang dipimpinnya. Penilaian kinerja ini dilihat dari bagaimana suatu devisi dalam mengelola biaya produksi yang akan mereka gunakan dalam menjalankan produksi. Berkaitan dengan penggunaan biaya dalam proses produksi pada pembuatan tinta cetak di PT. Cemani Toka, maka perlu dilakukan adanya biaya perencanaan atau anggaran biaya.

Tabel 6

Anggaran biaya produksi PT. Cemani Toka

Tahun 2013 dan 2014

\begin{tabular}{|l|r|r|}
\hline \multirow{2}{*}{ Biaya Produksi } & \multicolumn{2}{|c|}{ Anggaran (Rp.000) } \\
\cline { 2 - 3 } A. Bahan Baku : & \multicolumn{1}{|c|}{$\mathbf{2 0 1 3}$} & $\mathbf{2 0 1 4}$ \\
1. Pigment & 350.252 .000 & 304.796 .500 \\
2. Resin & 135.335 .600 & 125.820 .454 \\
3. Addictive & 26.706 .000 & 23.769 .760 \\
4. WX & 108.880 .000 & 118.090 .000 \\
\hline TOTAL & $\mathbf{6 2 1 . 1 7 3 . 6 0 0}$ & $\mathbf{5 7 2 . 4 7 6 . 7 1 4}$ \\
\hline B. TKL: & & \\
1. R\&D Offset & 727.239 & 804.249 \\
2. R\&D Gravure & 673.200 & 753.984 \\
3. Q. Assurence & 47.520 & 53.222 \\
4. Produksi 1 & 3.733 .237 & 4.315 .952 \\
5. Produksi 2 & 1.667 .668 & 1.995 .840 \\
6. Produksi 3 & 324.518 & 387.596 \\
7. Marketing & 490.304 & 594.226 \\
8. Procurment & 468.102 & 595.451 \\
\hline TOTAL & $\mathbf{8 . 1 3 1 . 7 8 8}$ & $\mathbf{9 . 5 0 0 . 5 2 1}$ \\
\hline C. Overhead : & & \\
1. Honorer & 554.778 & 561.493 \\
2. B. Sosial & 6.844 .246 & 6.541 .498 \\
3. B. Kesehatan & 290.125 & 143.505 \\
4. B. Air \& Listrik & 5.677 .964 & 6.008 .317 \\
5. B. Pen Barang & 71.131 & 46.691 \\
6. B. Pem Bahan & 3.363 .270 & 4.068 .796 \\
7. B. Perj Dinas & 457.714 & 435.120 \\
8. B. Pemeliharaan & 4.611 & 4.760 .129 \\
9. B. Percobaan & 693.625 & 140.441 \\
10.B. Tenaga Ahli & 384.436 & 450.626 \\
11.B. Embellage & 2.286 & 2.396 .043 \\
\hline TOTAL & $\mathbf{2 5 . 2 3 6 . 0 7 4}$ & $\mathbf{2 5 . 5 5 2 . 6 5 9}$ \\
\hline
\end{tabular}

JIAFE (Jurnal Ilmiah Akuntansi Fakultas Ekonomi)

Volume 2 No. 1 Tahun 2016 Edisi 2, Hal. 58-68 
Selanjutnya akan disajikan data realisasi biaya produksi yang telah digunakan oleh PT. Cemani Toka untuk periode tahun 2013-2014. Berikut ini adalah data mengenai biaya bahan baku yang telah digunakan untuk memproduksi tinta cetak selama periode tahun 2013-2014 yaitu sebagai berikut:

Tabel 7

Biaya Bahan Baku PT. Cemani Toka

Tahun 2013-2014

\begin{tabular}{|l|c|c|}
\hline \multirow{2}{*}{ Jenis Bahan Baku } & \multicolumn{2}{|c|}{ Biaya Bahan Baku (Rp.000) } \\
\cline { 2 - 3 } & $\mathbf{2 0 1 3}$ & $\mathbf{2 0 1 4}$ \\
\hline Pigment & 332.131 .948 & 222.583 .013 \\
\hline Resin & 136.267 .548 & 128.240 .228 \\
\hline Addictive & 25.664 .432 & 24.915 .066 \\
\hline WX & 108.287 .569 & 118.333 .079 \\
\hline \multicolumn{1}{|c|}{ Total } & $\mathbf{6 0 2 . 3 5 1 . 4 9 9}$ & $\mathbf{4 9 4 . 0 7 1 . 3 8 7}$ \\
\hline
\end{tabular}

Sumber: data laporan bahan baku dari devisi purchasing PT. Cemani Toka *)rata-rata harga beli dalam 2 tahun

Besarnya pengeluaran yang digunakan oleh PT. Cemani Toka untuk periode tahun 2013-2014, sebagai biaya tenanga kerja langsung selama berikut:

\section{Tabel 9}

Biaya Tenaga Kerja Langsung PT. Cemani Toka

Tahun 2013-2014

\begin{tabular}{|l|r|r|}
\hline \multirow{2}{*}{\multicolumn{1}{|c|}{ TKL }} & \multicolumn{2}{|c|}{ Biaya TKL (Rp.000) } \\
\cline { 2 - 3 } & Tahun 2013 & Tahun 2014 \\
\hline R\&D Offset & 718.080 & 862.960 \\
\hline R\&D Gravure & 670.299 & 711.240 \\
\hline Quality Assurence & 31.488 & 52.826 \\
\hline Produksi 1 & 3.999 .600 & 4.479 .552 \\
\hline Produksi 2 & 1.782 .000 & 1.998 .821 \\
\hline Produksi 3 & 277.200 & 310.464 \\
\hline Marketing & 480.480 & 538.137 \\
\hline Procurment & 448.800 & 502.656 \\
\hline \multicolumn{1}{|c|}{ Total } & $\mathbf{8 . 4 0 7 . 9 4 7}$ & $\mathbf{9 . 4 5 6 . 6 5 8}$ \\
\hline
\end{tabular}

Sumber : data laporan summary gaji devisi keuangan PT. Cemani Toka

Untuk biaya overhead pabrik yang dikeluarkan oleh PT. Cemani Toka untuk periode tahun 2013-2014 adalah sebagai berikut:

\section{Tabel 10}


Biaya Overhead Pabrik PT Cemani Toka

Tahun 2013-2014

\begin{tabular}{|l|r|r|}
\hline \multirow{2}{*}{ Uraian } & \multicolumn{2}{|c|}{$\begin{array}{c}\text { Overhead Pabrik } \\
\text { (Rp.000) }\end{array}$} \\
\cline { 2 - 3 } & \multicolumn{1}{|c|}{$\mathbf{2 0 1 3}$} & \multicolumn{1}{c|}{$\mathbf{2 0 1 4}$} \\
\hline Honorer & 504.343 & 536.276 \\
\hline B. Sosial & 6.222 .042 & 6.230 .395 \\
\hline B. Kesehatan & 263.750 & 130.317 \\
\hline B. Air \& Listrik & 5.976 .804 & 6.605 .998 \\
\hline B. Pen.Barang & 64.664 & 43.458 \\
\hline B. Pem. Bahan & 3.057 .518 & 3.915 .920 \\
\hline B. Perj. Dinas & 416.103 & 414.315 \\
\hline B. Pemeliharaan & 4.854 .534 & 4.517 .402 \\
\hline B. Percobaan & 630.568 & 108.912 \\
\hline B. Tenaga Ahli & 349.488 & 433.152 \\
\hline B. Embellage & 2.079 .070 & 2.292 .089 \\
\hline \multicolumn{1}{|c|}{ Total } & $\mathbf{2 4 . 4 1 8 . 8 8 9}$ & $\mathbf{2 5 . 2 2 8 . 2 4 0}$ \\
\hline
\end{tabular}

Sumber : data laporan biaya overhead pabrik arsip dari devisi keuangan PT. Cemani Toka

\subsection{Laporan Pertanggungjawaban Terhadap Kinerja Bagian Produksi \\ Berkaitan dengan uraian} sebelumnya, maka selanjutnya penulis akan menyajikan laporan pertanggungjawaban dari bagian produksi PT. Cemani Toka periode 2013-2014, untuk mengetahui apakah laporan tersebut telah sesuai dengan yang diharapkan oleh perusahaan. Laporan pertanggungjawaban ini berisi tentang data mengenai realisasi biaya produksi dan data perencanaan biaya yang sudah di uraikan sebelumnya pada tabel 6 sampai tabel 10 dari data tersebut penulis akan membandingkan data tersebut dan melakukan analisis varian untuk mengetahui apakah hasil perbandingan tersebut menyatakan favorabel atau unfavorabel.

\subsection{Penerapan \\ Akuntansi Pertanggungjawaban Sebagai Alat Bantu Manajemen Dalam}

\section{Menilai Kinerja Bagian Produksi \\ Dari uraian yang telah dijelaskan,} penerapan akuntansi pertanggungjawaban bagian produksi pada PT. Cemani Toka dimulai dari penyusunan hingga pelaksanaan anggaran telah dilakukan dengan cukup baik. Laporan pertanggungjawaban bagian produksi dapat dijadikan acuan manajer yang bertanggungjawab pada bagian produksi untuk menghasilkan laporan pertanggungjawaban yang lebih baik lagi.

Pengukuran kinerja setiap pusat pertanggungjawaban memberikan dasar dalam melakukan penilaian kinerja bagian yang terdapat dalam perusahaan, serta untuk memotivasi para manajer dalam menjalankan tugasnya sesuai dengan tujuan yang telah ditetapkan oleh perusahaan. Kegiatan produksi dan laporan produksi yang telah disajikan sebelumnya oleh PT. Cemani Toka, bahwa dalam menjalankan kegiatannya selalu memperhatikan biaya yang akan 
digunakan. Sehingga dapat dikatakan bahwa kinerja untuk manajer yang bertanggungjawab pada bagian produksi sudah efisien dan efektif dalam mengendalikan biayanya. Manajer bagian produksi selain mempertimbangkan biaya yang dikeluarkan oleh bagian produksi, juga memperhatikan kualitas dari produknya. PT. Cemani Toka ini sangat memperhatikan kualitas dari produksinya sehingga tidak mengecewakan pelanggan. Meskipun terdapat banyak pesaing yang memiliki produk lebih murah dan ketepatan waktu dalam menghasilkan produksinya, PT. Cemani Toka yakin bahwa pelanggan tidak akan pindah ke produk luar yang sejenis karena kualitas produk sangat diutamakan.

Berdasarkan tujuan yang telah diuraikan pada bab sebelumnya, penulis berpendapat bahwa akuntansi pertanggungjawaban dari PT. Cemani Toka telah dilaksanakan sesuai dengan yang diharapkan oleh perusahaan dan dalam pembagian tugas telah terstruktur dengan baik sehingga setiap bagian memiliki tanggungjawab masing masing yang harus dijalankan. Untuk kinerja bagian produksi juga telah berjalan dengan cukup efektif dan efisien, karena sudah melakukan perencanan biaya dan realisasi yang cukup baik. Hal ini dapat digunakan untuk dasar manajer dalam menjalankan kegiatan produksi untuk tahun yang akan datang. Sehingga untuk penerapan akuntansi pertanggungjawaban sebagai alat bantu manajemen dalam menilai kinerja bagian produksi ini berpengaruh terhadap keberhasilan perusahaan. Dari akuntansi pertanggungjawaban yang dilaporkan oleh setiap bagian pertanggungjawaban tersebut dapat digunakan sebagai dasar untuk mengetahui sejauh mana kinerja dari tiap-tiap manajer yang bertanggungjawab. Sehingga manajer juga termotivasi untuk menghasilkan laba.

\section{SIMPULAN}

Berdasarkan hasil dari penelitian mengenai penerapan akuntansi pertanggungjawaban sebagai alat bantu manajemen dalam menilai kinerja bagian produksi pada PT. Cemani Toka, maka penulis dapat menarik kesimpulan dari hasil penelitian yaitu sebagai berikut :

1. Penerapan akuntansi pertanggungjawaban PT. Cemani Toka telah dikakukan dengan baik, karena perusahaan telah membagi tugas dan wewenang secara jelas pada setiap bagian sesuai struktur organisasi yang telah dibuat. Untuk penyususnan anggran PT. Cemanai Toka juga telah melakukan perencanaan yang baik dalam melakukan produksinya. Perencanaan yang baik ini telah dilakukan dengan adanya anggaran biaya yang digunakan untuk dasar dalam pengendalian biaya. PT. Cemani Toka juga telah menggunakan kode rekening dalam perkiraan pada setiap akunnya. Laporan peranggungjawaban juga telah dilakukan dengan baik karena tiap departemen telah menyusun laporan pertanggungjawaban. Tetapi PT. Cemani Toka belum melakukan kalsifikasi biaya antara biaya terkendali dengan biaya tidak terkendali.

2. Kinerja bagian produksi pada PT. Cemani Toka sudah menunjukkan kinerja yang cukup baik. Bagian produksi sudah membuat laporan pertanggungjawaban biaya produksi secara lengkap, dari laporan biaya produksi manajer dapat membandingkan dengan anggaran biaya produksi sehingga manajer produksi dapat mengendalikan biaya. Hal ini dapat dilihat secara keseluruhan dari tahun 2013-2014 biaya produksi yang dikeluarkan tidak melebihi dari anggaran 
biayanya, hanya saja pada tahun 2013 pada biaya tenaga kerja langsung mengalami varians tidak menguntungkan sebesar Rp276.159.195 ini disebabkan oleh beberapa faktor.

3. Berdasarkan dari hasil penelitian menunjukkan bahwa penerapan akuntansi pertanggungjawaban sebagai alat bantu manajemen dalam menilai kinerja bagian produksi pada PT. Cemani Toka mempunyai peran yang sangat penting dalam menilai kinerja dari pusat-pusat pertanggungjawaban. PT. Cemani Toka telah menjalankan akuntansi pertanggungjawabannya dalam kegiatan produksinya, terlihat dari seluruh rincian kegiatan produksi yang dilaporkan sesuai dengan tugas dan wewenang yang sudah ditetapkan.

\section{DAFTAR PUSTAKA}

Anthony, Robert N., dan Vijay Govindarajan. 2009. Sistem Pengendalian Manajemen. Alih Bahasa: F.X Kurniawan Tjakrawala. Buku 1, Salemba Empat, Jakarta.

Anthony, Robert N., dan Vijay Govindarajan. 2009. Sistem Pengendalian Manajemen. Alih Bahasa: F.X Kurniawan Tjakrawala. Buku 2, Salemba Empat, Jakarta.

Armila Krisna Warindrani. 2006. Akuntansi Manajemen. Edisi 1. Graha Ilmu: Yogyakarta.

Carter, William K. 2011. Akuntansi Biaya. Buku 2. Edisi 15. Salemba Empat, Jakarta.

Darsono Prawironegoro. 2005. Akuntansi Manajemen. Edisi 1, Diadit Media, Jakarta.

Edy Sukarno. 2007. Sistem Pengendalian Manajemen: Suatu
Pendekatan Praktis. PT. Gramedia Pustaka Utama, Jakarta.

Garrison, Ray H., Eric W. Noteen, and Peter C, Brewer. 2006. Akuntansi Manajerial. Buku 1. Edisi 11, Salemba Empat, Jakarta.

Hansen, Don R., Dan Maryanne, M. Mowen. 2004. Managemen Accounting. Buku 1. Edisi 7, Alih Bahasa: Dewi Fitriasari dan deny Arnes Kwary, Salemba Empat, Jakarta.

Hansen, Don R., Dan Maryanne, M.

Mowen. 2013. Akuntansi

Manajerial. Buku 1. Edisi 8, Salemba Empat, Jakarta.

Henry Simamora. 2012. Akuntansi Manajemen. Salemba Empat, Jakarta.

Mulyadi. 2007. Akuntansi Manajemen : Konsep, Manfaat dan Rekayasa. Edisi 7, Salemba Empat, Jakarta.

Mulyadi., dan Johny Setyawan. 2001. Sistem Perencanaan Pengendalian, Manajemen, Sistem Pelipat Ganda Kinerja Perusahaan. Edisi 2. Cetakan ke 1, Salemba Empat, Jakarta.

Pertama. Yogyakarta: BPFE.

Robbins, Stephen P. and Mary Coulter. 2010. Manajemen. Jilid 1. Edisi 10, Erlangga, Jakarta.

Rudianto. 2013. Akuntansi Manajemen : Informasi Untuk Pengambilan Keputusan Manajemen. PT Grasindo, Jakarta.

Sartika Setia Sari. 2013. Penerapan Akuntansi Pertanggungjawaban sebagai alat bantu Manajemen dalam Menilai Kinerja Bagian Produksi pada PT. Cahaya Buana Intitama. STIE Kesatuan, Bogor.

Siregar, Baldric,. Bambang Suripto, Dody Hapson, Eko Widodo Lo, dan Frasto Biyanto. 2014. Akuntansi Manajemen. Salemba Empat, Jakarta. 
Veithzal Rivai \& Ahmad Fawzi Mohd Basri. 2005. Performance Appraisal Sistem Yang Tepat Untuk Menilai Kinerja Karyawan Dan Meningkatkan Daya Saing Perusahaan. PT. Raja Grafindo Persada, Jakarta.
Welsch, Glenn A., Ronald W. Hiltong, dan Paul N. Gordon. 2000. Anggaran Perencanaan dan Pengendalian Laba. Buku 1, Salemba Empat, Jakarta. 